lasted four days and consisted of lectures, demonstrations and practical work. Cyclostyled summaries of the nine lectures delivered during the course have been collected together in A.E.R.E. H.P./L.23, an unclassified publication which is now available for purchase (H.M.S.O., 13s. 3d. net). The subjects of the lectures included: "Elements of Nuclear Physics" (R. A. Faires) ; "The Organization of a Radiation Protection Service" (I. S. Jones); "Units in Radiation and the Detection of Radiation" (H. J. Dunster); "The External Radiation Hazard and its Control" (E. M. Flew); and "Decontumination and Waste Disposal" (R. H. Burns).

\section{Traffic Problems in Britain}

THE present level of use of motor-vehicles in Great Britain was reached many years ago in the United States and it is desirable that we should profit by experience there when we decide how to tackle our traffic problems. That presumably is the object of the recent P.F.P. pamphlet, "Solving Traffic Problems: I essons from America", and in it one might reasonably expect to find factual information as to the value or otherwise of American practice. Unfortunately, the report is confined almost entirely to quotations of American opinion, some of which fairly certainly comes from people with vested interests in particular branches of transport. It is thus diflicult to know from the supporting evidence what value to attach to the conclusions drawn. It is particularly important that we should draw on American experience of the value of urban motorways in solving traffic problems. The report, however, gives no information such as Mr. Arthur S. Hodgkiss, the eminent and experienced expert from New York, gave to the recent conference in London on urban motorways when, in speaking of conditions in Great Britain, he expressed the view that "the development of urban motorways as a part of a national system of modern highways will more than pay for itself through direct and intangible benefits". Instead, the report emphasizes possible difficulties which might arise from the use of these roads by large amounts of car traffic travelling to and from work. Of course, the report is right in drawing the conclusion that the urban motorway will not of $i$ self solve the traffic problem of Britain, which must be considered in relation to other factors and in particular to public transport and to parking policy.

It is disappointing, however, that the report can provide no clear indication from the United States as to whether the various restrictive measures that it seems to advocate are likely to be either acceptable or successful; whether in fact a proper balance which the report says "must be achieved between private and public transport" has been achieved anywhere; and whether it would be considered in the United States profitable to wait until traffic needs are "properly defined", whatever that may mean in present rapidly changing conditions, before getting on with the job. Great efforts should, of course, be made to collect facts-indeed, the Americans are the world's great fact collectors; but in reviewing American opinion, it is significant that Mr. Hodgkiss recommended the building of one urban motorway in Great Britain, so that we could see for ourselves the advantages that it gave, and suggested that if we studied too long in highway matters everyone became scared. This is an American 'get-on-with-the-job attitude' to which the report does not refer, but which is still held strongly in America's biggest city.
It is indeed true that the United States has not solved the problem of traffic congestion; but it is a fact that the American cries out for more and more urban highway capacity. It would be wrong to convey the impression that the urge is diminishing, although it is right to say that more thought is being given to the better integration of all forms of transport, and to the conditions of use and to the provision of parking facilities.

\section{Water Research News}

REsEaRCH in Great Britain on problems concerned with the availability and treatment of water for domestic supply was, for many years, carried out mainly by the technical staffs of local authorities. It had long been felt, however, that some central organization for conducting research in this field was desirable and the Institution of Water Engineers formed a Research Committee which, working through a number of grour.s, stimulated work on some of the many problems with which the water industry is concerned. 'This organization, though it did a great deal to foster research, suffered from the disadvantage that it had no permanent staff and could therefore act for the most part only as a co-ordinating body. In 1953 the British Waterworks Association, which represents all the public water undertakings in Great Britain, in conjunction with the Institution of Water Engineers, formed a Water Research Association, which last year appointed a permanent staff, housed, for the moment, in a large house at Redhill, Surrey. It is this body which has just issued the first number of Water Research News, a publication which is very attractively written and produced. It contains notices of two of the first technical publications of the Association- on instruments available for the detection of leaks in water mains, and on the treatment of aggressive water by aeration-together with short articles on the permeability of polythene to coal gas (a problem which has arisen in a few instances where polythene water pipes have been used), and on cathodic protection of buried mains.

\section{Spaceflight}

THE British Interplanetary Society was founded in 1933 to promote the development of interplanetary exploration and communication by the study of rocket engineering, astronomy and other associated sciences, and it now includes among its members many British and foreign workers prominent in these fields. For many years the Society has published a bi-monthly journal, issued free to members, containing original papers of a highly technical and research nature. However, there is now a growing public interest in astronautics and since one of the Society's aims is to ensure the spreading of correct information, a new publication, spaceflight, in addi. tion to the Society's journal has been launched. Spacefight, the first popular magazine of its kind, will appear quarterly and aims at giving a picture of the research work being undertaken as well as discussing related historical and astronomical matters. The first number contains a typical 'mixed bag'. 'The introductory article "Wlight into Space", by W. N. Neat, gives a general introduction to the new science of astronautics and clears up a number of popular misconceptions about the basic principles and methods to be used. "Ideas behind the Rocket", by D. Hurden, is a very clear statement of the principle of rocket propulsion, what rockets look like and of the performance to be expected, and "The Vanguard 